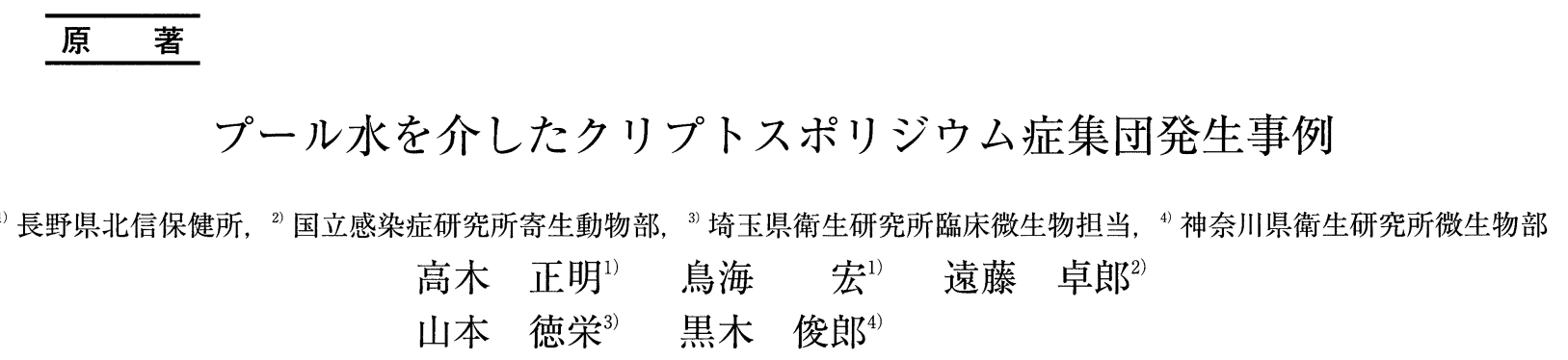

(平成 19 年 8 月 27 日受付)

(平成 19 年 10 月 22 日受理)

Key words : cryptosporidiosis, outbreak, swimming pool

平成 16 年 8 月下旬, 長野県北信地方でプール, 体育館等の運動施設を有する宿泊施設の利用客において, 水系クリプトスポリジウム集団感染が発生した，集団感染は 8 月下旬に始まり，8月 $27 ， 28$ 日をピークと して，9月初めには収束した，所轄の保健所の調查では，水様性下痢，嘔吐，腹痛，裏急後重（テネスムス） などの消化器症状を呈する患者数は 288 名であることが判明した．発症者の中で検便を実施した 86 名のう ち 74 名 (86.0\%) から Cryptosporidium sp. のオーシストが検出された。記述疫学, 環境調查, 臨床材料検 查等の結果, 施設利用以前に感染していた発症者がプール内で顀便污染を起こしたことが原因と考えられ, プール利用者 222 名が発症した．また，当プールの利用歴がない者 66 名も感染していることが判明した．調 查の結果，同施設の便所近くにある体育館廊下において，1 人の患児が下痢の失禁を起こした．この事故の 清掃処理は手洗い場で行われ，それによって蛇口，流し（シンク）等が污染された，この場所において感染 者グループの一員が, 粉末飲料を水で溶解する際に素手で攪找し，それを飲んだ人達も感染したと考えられ た.

〔感染症誌 $82 ： 14 \sim 19,2008$ ]

\section{序文}

クリプトスポリジウム症は胞子虫類に属する原虫ク リプトスポリジウム（Cryptosporidium spp.）のオー シストを経口摂取することで感染し, 原虫が腸管上皮 細胞に寄生・増殖することにより発症する疾患であ $ろ^{1)}$. 本原虫は下痢症の原因の 1 つで, その感染形で あるオーシストが塩素等の化学薬品による消毒に対し て強い抵抗性を示すことから, 水道などの水系を介し た集団感染に強い関心が寄せられている 米では水泳プールなどのレクリエーション水を介した 感染が問題となっており ${ }^{677)}$ ，米国 CDCの報告によれ ば水系集団感染による胃腸症の相当数がクリプトスポ リジウムに起因すること，1991 年から 2002 年の期間 にクリプトスポリジウムによる水系感染が 62 件発生 し，そのうち 50 件 $(80.6 \%)$ が水泳プールなどのリ クリエーション水を介した事例であったとされてい る4). しかしながら，わが国ではこれまでに水泳プー ルを介した集団感染事例の報告は知られていない. 今

別刷請求先：（テ390-0852）長野県松本市大字島立 1020 松本保健所食品・生活衛生課高木 正明
回, 我々は平成 16 年 8 月下旬にプールを介してクリ プトスポリジウムに集団感染したと思われる事例を経 験したので報告する.

\section{対象と方法}

平成 16 年 8 月 31 日, 「8 月 20 日から 24 日の間, 長 野県北信地方でプールや体育館等の運動施設を持つ Z 宿泊施設において，水泳合宿をしたA スポーツで下 痢等の患者が多数発生した.」との情報を受けて，食 中毒，感染症を疑い，直ちに調査を開始した． 9 月 2 日に千葉市およびさいたま市の発症者便からクリプト スポリジウムのオーシストが検出されたことから, 本 原虫による水系感染に重点を置いた調查および検査を 実施した。また，9月 7 日から 8 日には厚生労働省水 道水質管理室を中心とした調査団が来県し，合同調査 を行った。

1. 聞き取り調查

1）健康状態, 契食状況及び行動

8 月 20 日から 8 月 24 日において, 当該 $Z$ 宿泊施設 を利用した利用客を対象に, 利用客の居住地を管轄す る自治体に依頼して聞き取り調查を行った。 
健康状況については, 症状の有無, 程度, 初発日時 等の質問を行った，契食状況については，Z 宿泊施設 が提供した食事の献立ごとの喫食の有無, 他食品摂食 状況, 飲水の状況, 水の使用の有無等を調べた. 行動 については, 滞在中の宿泊階及び部屋, 便所, 風呂, 食堂，運動施設の使用状況について調べた．同様に， $Z$ 宿泊施設の従事者 47 人に対し, 健康状況及び契食 状況を調查した。

2）調理施設，給水施設，客室及び共同浴場

施設の構造及び管理状況について聞き取り調査及び 実地検分を実施した。

2. 微生物学的検査

1）細菌及びウイルス

発症者便，調理従事者便，Z宿泊施設で調理した食 品を対象に, 常法により食中毒原因細菌およびノロウ イルスの分離を試みた，細菌学的検査においては，必 要に応じて増菌培養を併用し，選択培地による分離培 養を行い, 平板上の疑わしい集落を生化学的性状なら びに市販抗血清による同定を行った.

2) クリプトスポリジウム

（1）顕微鏡観察

$Z$ 宿泊施設における水道水, 調理室で製水した氷お よび井戸の原水, 全 6 検体に関するクリプトスポリジ ウムの検査, 調理従事者の糞便 7 検体に関する原虫検 查は，埼玉県衛生研究所に依頼した。水試料はクリプ トスポリジウム暫定対策指針の方法に従って検査を 行った. また, 粪便検査は直接薄層塗抹法, ホルマリ ン・エーテル法およびショ糖遠心浮遊法を併用し, ク リプトスポリジウムのオーシストは, 抗酸染色, 蛍光 抗体法および微分干涉装置による鏡検によって同定し た.

同施設を利用した有症者の検便については，その居 住地を管轄する都県市に検査を依頼した.

プールのろ過砂上の凝集沈殿物，プール排水溝沈殿 物, 浴場ヘアーキャッチャー内残椬, プールに隣接し た池の底泥，下痢便に污染された体育館手洗い場の床 材および同場所の清掃に用いたタオルは, 神奈川県衛 生研究所で検体処理を行った.

プールろ過砂上の凝集沈殿物は塩酸あるいは硫酸酸 性下で沈殿物を溶解し, その上清を $2,800 \mathrm{rpm}, 10$ 分 間の遠心操作により沈椬を回収した，沈椬をリン酸緩 衝生理食塩水（PBS, pH7.4）に再浮遊したものを試 料として, 以下, 常法に従って遠心沈殿法, 免疫磁気 ビーズ法 (Dynabeads anti-Cryptosporidium kit, Dynal）によりオーシストを分離・精製した.

粪便污染の確認された足拭きマットに関しては，污 染箇所 $(15 \mathrm{~cm} \times 15 \mathrm{~cm})$ を $0.1 \%$ Tween 80 加 PBS に浸 し, 薬匙でマット表側の植毛部分から内層までを強く
掻き洗いをし, 洗浄液を回収した. 次いで, 細切した マットを 5 分間のストマッカー処理を行い, 洗浄液を 回収した：それぞれの回収液を試料として，2,800 $\mathrm{rpm}, 10$ 分の遠心沈殿により沈椬を回収した. 得ら れた沈椬の一部に対して免疫磁気ビーズ法によりオー シストの精製を行った. 得られた精製物を蛍光抗体法, および微分干渉顕微鏡によりオーシストの確認を行っ た.その他の環境試料も同様に処理し，オーシストの 確認を行った.

（2）遺伝子解析

各患者グループから得られたクリプトスポリジウム 臨床分離株, および顕微鏡観察で多量のオーシストが 観察された足拭きマット由来の株を用いて遺伝子解析 を行った. 各濃縮精製試料を再度免疫磁気ビーズ法で 精製し, 得られたオーシストより DNA Stool Mini Kit （QIAGEN）を用いてDNAを抽出し，これを鋳型と してポリスレオニン遺伝子の一部領域（Poly-T 領域） ならびに $18 \mathrm{~S}$ rRNA を標的としたPCR を行い, 予定 された断片長の PCR 産物を得た. すなわち, Poly-T 領域を標的とした PCR ではプライマー（CRY44:5’CTC TTA ATC CAA TCA TTA CAA C-3',CRY 373 : 5'AGC AGC AAG ATA TGA TAC CG-3’) を用 い, 45 サイクルの伸長反応を行い約 $520 \mathrm{bp}$ の PCR 増 幅産物を得た。一方, 18SrRNA 遺伝子の増幅は Xiao et al. (1999)の方法に従い Nested PCR を行った.す なわち, 一次反応には約 $1.3 \mathrm{kbp}$ を増幅領域としたプ ライマー (5'TTC TAG AGC TAA TAC ATG CG-3’ 並びに 5’-CCC ATT TCC TTC GAA ACA GGA-3)を 用い, 二次反応には一次反応液を鋳型としプライマー (5’-GGA AGG GTT GTA TTT ATT AGA TAA AG3’並びに 5'-AAG GAG TAA GGA ACA ACC TCC A3）を用いた．伸張反応は 40 サイクルとし，約 $840 \mathrm{bp}$ の PCR 増幅産物を得た. 得られた PCR 産物より, BigDye Terminator Cycle Sequencing Kit V1.1 ならびに ABI Prism 310 Genetic Analyzer (AppliedBiosystems）を用いて直接塩基配列決定を行った.

\section{結 果}

\section{1. 発症状況}

同時期に宿泊施設を利用したのは 12 グループ (AL） 592 名で (Table 1), 調査協力を得た 578 名のう ち, A スポーツ 222 名 (調査済数 261 名), C大 25 名 (同 36 名), D大 32 名（同 39 名）及び $\mathrm{E}$ 高 9 名（同 20 名)の 4 グループで計 288 名の発症者があった（Table 2). 他の 8 グループからは発症者は認められな かった. 8 月 18 日から 23 日までの期間に, 上記 4 グ ループにおいて下痢等の消化器症状は，1日に 1 名か ら 4 名に見られた。患者は 24 日から 29 日までの期間 に集中し，発症曲線は全体では 27 日および 28 日を 
Table 1 Subjects

\begin{tabular}{crrrrll}
\hline Group & No. & Interviewed & Affected & Rate $\%$ & Stay & Remarks \\
\hline A & 273 & 261 & 222 & 85.1 & $8 / 20-8 / 24$ & M\&F *, elementary and junior high school, swimming \\
B & 27 & 27 & 0 & 0.0 & $8 / 15-8 / 26$ & M, university, volleyball \\
C & 36 & 36 & 25 & 69.4 & $8 / 17-8 / 23$ & M\&F, university, kendo \\
D & 41 & 39 & 32 & 82.1 & $8 / 17-8 / 23$ & M\&F, university, kendo \\
E & 20 & 20 & 9 & 45.0 & $8 / 19-8 / 23$ & F, high school, volleyball \\
F & 20 & 20 & 0 & 0.0 & $8 / 19-8 / 23$ & F, high school, volleyball \\
G & 29 & 29 & 0 & 0.0 & $8 / 20-8 / 24$ & M, high school, hand ball \\
H & 22 & 22 & 0 & 0.0 & $8 / 21-8 / 23$ & F, elementary school, volleyball \\
I & 22 & 22 & 0 & 0.0 & $8 / 22$ & elderly mallet golf \\
J & 23 & 23 & 0 & 0.0 & $8 / 22-8 / 23$ & elderly \\
K & 17 & 17 & 0 & 0.0 & $8 / 22-8 / 24$ & M, university, volleyball \\
L & 62 & 62 & 0 & 0.0 & $8 / 23-8 / 27$ & M\&F, junior high school, basketball \\
\hline Total & 592 & 578 & 288 & 49.8 & & \\
\hline
\end{tabular}

* M: male, F: female

Table 2 Persons affected, by group

\begin{tabular}{|c|c|c|c|c|c|c|c|c|c|c|c|c|c|c|c|c|c|c|c|c|}
\hline \multirow{2}{*}{ Date } & \multicolumn{4}{|c|}{ A } & \multicolumn{4}{|c|}{$\mathrm{C}$} & \multicolumn{4}{|c|}{ D } & \multicolumn{4}{|c|}{$\mathrm{E}$} & \multicolumn{4}{|c|}{ total } \\
\hline & & & $\mathrm{M}$ & $\mathrm{F}$ & & & M & F & & & $\mathrm{M}$ & $\mathrm{F}$ & & & M & $\mathrm{F}$ & & & $\mathrm{M}$ & $\mathrm{F}$ \\
\hline 18 Aug. & 1 & $(1 / 1)$ & & 1 & 0 & & & & 2 & $(0 / 1)$ & & 2 & 0 & & & & 3 & $(1 / 2)$ & 0 & 3 \\
\hline 19 Aug. & 0 & & & & 0 & & & & 3 & $(0 / 1)$ & & 3 & 0 & & & & 3 & $(0 / 1)$ & 0 & 3 \\
\hline 20 Aug. & 0 & & & & 0 & & & & 1 & & & 1 & 0 & & & & 1 & & 0 & 1 \\
\hline 21 Aug. & 1 & & 1 & & 0 & & & & 2 & $(0 / 1)$ & 1 & 1 & 0 & & & & 3 & $(0 / 1)$ & 2 & 1 \\
\hline 22 Aug. & 3 & & 1 & 2 & 0 & & & & 1 & & 1 & & 0 & & & & 4 & & 2 & 2 \\
\hline 23 Aug. & 3 & & & 3 & 0 & & & & 0 & & & & 0 & & & & 3 & & 0 & 3 \\
\hline 24 Aug. & 19 & $(2 / 2)$ & 7 & 12 & 1 & $(0 / 1)$ & 1 & & 1 & & 1 & & 0 & & & & 21 & $(2 / 3)$ & 9 & 12 \\
\hline 25 Aug. & 19 & $(6 / 6)$ & 12 & 7 & 3 & $(3 / 3)$ & 3 & & 3 & & 3 & & 1 & $(0 / 1)$ & & 1 & 26 & $(9 / 10)$ & 18 & 8 \\
\hline 26 Aug. & 23 & $(6 / 6)$ & 14 & 9 & 6 & $(6 / 6)$ & 6 & & 1 & & 1 & & 0 & & & & 30 & $(12 / 12)$ & 21 & 9 \\
\hline 27 Aug. & 62 & $(12 / 12)$ & 34 & 28 & 8 & $(6 / 8)$ & 7 & 1 & 2 & $(0 / 1)$ & 2 & & 0 & & & & 72 & $(18 / 21)$ & 43 & 29 \\
\hline 28 Aug. & 60 & $(12 / 12)$ & 33 & 27 & 4 & $(4 / 4)$ & 3 & 1 & 2 & & 2 & & 0 & & & & 66 & $(16 / 16)$ & 38 & 28 \\
\hline 29 Aug. & 22 & $(3 / 3)$ & 12 & 10 & 1 & $(1 / 1)$ & 1 & & 7 & $(0 / 1)$ & 7 & & 5 & $(5 / 5)$ & & 5 & 35 & $(9 / 10)$ & 20 & 15 \\
\hline 30 Aug. & 2 & & 1 & 1 & 1 & & 1 & & 1 & $(0 / 1)$ & 1 & & 3 & $(2 / 3)$ & & 3 & 7 & $(2 / 4)$ & 3 & 4 \\
\hline 31 Aug. & 1 & & & 1 & 1 & $(0 / 1)$ & 1 & & 4 & $(1 / 1)$ & 4 & & 0 & & & & 6 & $(1 / 2)$ & 5 & 1 \\
\hline 1 Sep. & 1 & & & 1 & 0 & & & & 1 & & 1 & & 0 & & & & 2 & & 1 & 1 \\
\hline unknown & 5 & $(3 / 3)$ & 1 & 4 & 0 & & & & 1 & $(1 / 1)$ & & & 0 & & & & 6 & $(4 / 4)$ & 1 & 4 \\
\hline Total & 222 & $(45 / 45)$ & 116 & 106 & 25 & $(20 / 24)$ & 23 & 2 & 32 & $(2 / 8)$ & 24 & 7 & 9 & $(7 / 9)$ & 0 & 9 & 288 & $(74 / 86)$ & 163 & 124 \\
\hline
\end{tabular}

M: male, F: female

( ): laboratory confirmed cryptosporidiosis

ピークとする一峰性を示した（Fig. 1)。その間の発 生動向は, 24 日から 26 日までは, 21 名から 30 名程 度の発症者で推移し，27 日および 28 日には 72 名, 66 名とピークに達し, 続く 29 日には 35 名, さらに 30 日，31 日には 7 名および 6 名と急激に減少した。こ の間の下痢症患者の $86.8 \%$ は, 24 日から 29 日に集中 していた (Table 2).

当該集団感染の患者にみられた主な症状は，下痢 $(95.8 \%)$, 発熱 $(78.6 \%)$, 腹痛 $(72.6 \%)$ であった. 下痢はほとんどが水様性で，1日あたり 1 回から 10 数回みられた。 その他, 吐き気, 嘔吐, 頭痛, 悪寒, 倦总感, あい気（げっぷ）, 食思不振, 裏急後重, 咽 頭痛，咳等が報告された，尚，本事例は複数の自治体 にまたがり，それぞれで調査が行われたことから，各 自治体から報告された有症状者は，すべて発症者とし
て扱うこととした.

\section{2. 喫食状況}

食品や施設・設備, 調理従事者の調査, 既知の食中 毒原因細菌・ウイルス検査結果に, 食中毒を疑うもの はなかった。

\section{3. 環境調査}

水道施設は, 飲用の自家用井戸I（深度約 $100 \mathrm{~m}$ ) と プール用の自家用井戸 II（深度約 $450 \mathrm{~m}$ ）が独立して 設備されていた．いずれの井戸もコンクリートによる 井筒等の構造が整っており, 污水や雨水等の混入から 病原微生物污染に至るような状況にはなかった。飲用 の井戸では別途に貯水槽が設けられ，槽内に塩素注入 が行われていた，一方，水泳プールは加温装置，次亜 塩素酸ナトリウム注入装置, および直接凝集砂ろ過装

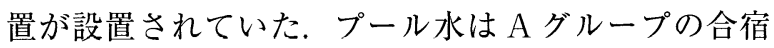


Fig. 1 Distribution of patient onset by day $(\mathrm{n}=282)$

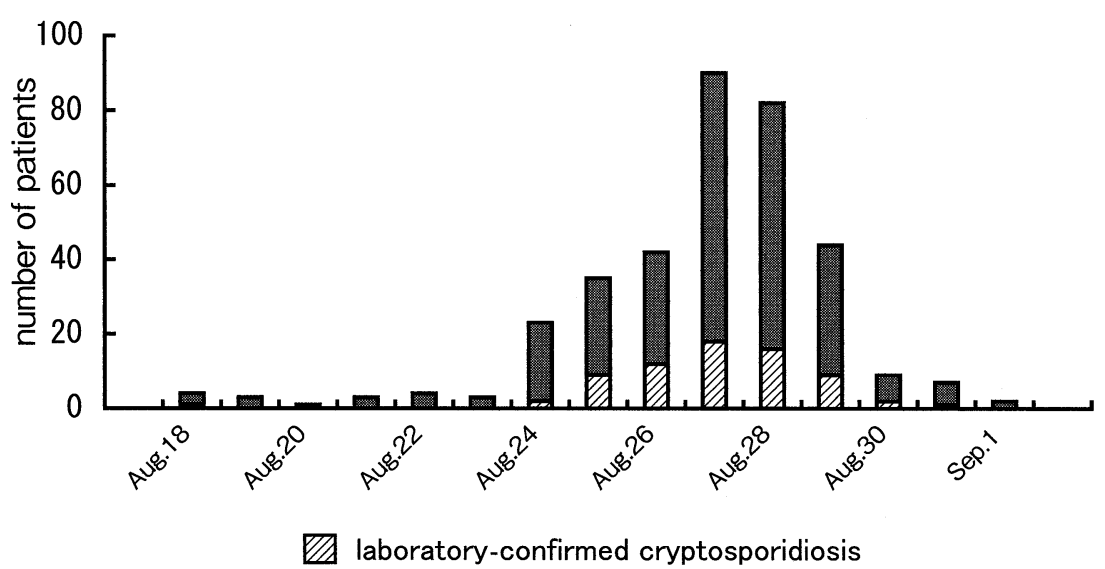

Fig. 2 Gymnasium washroom site of fecal accident. Part of carpet (arrow) stained by a fecal accident at the toilet entrance $(*)$ was dissected and examined for the presence of Cryptosporidium oocysts.

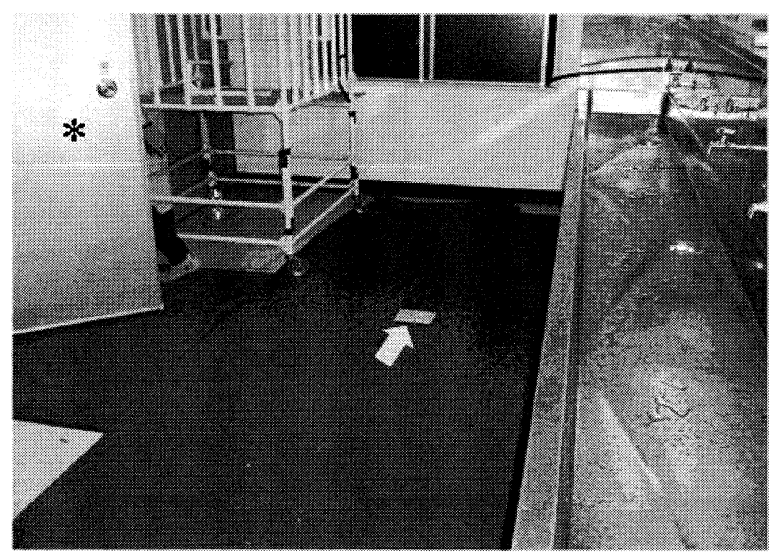

終了を機に使用を終了しており，実地検分時にはすで に水抜き，洗浄が行われた後であった。

4. グループ別行動状況

1）宿泊施設内の行動：部屋割り, 食事場所, 浴場, 便所の使用等に問題はなかった.

2）運動施設の使用状況：プールは $25 \times 33 \times 1.3 \mathrm{~m}$ で，A スポーツが 8 月 20 日午後から 24 日午前まで 使用し, その後, 排水, 清掃されていた，構造に問題 は見られず，プール水の残留塩素の検査結果記録は基 準を満たしていた. 他のグループの使用はなかった. 体育館は, B大, C大, D大, E 高, F 高, K大, L 中が使用していた。

3)練習時の飲水 : プール, 体育館を使用したグルー プのうち, B大, L中は市販のスポーツドリンクを, 他のグループは体育館手洗い場の給水栓等から水道水 を飲んでいた，体育館の手洗い場は便所出入り口前に あり，便所の手洗い流しを兼ねていた (Fig. 2).C大, $\mathrm{D}$ 大, $\mathrm{E}$ 高, $\mathrm{F}$ 高, $\mathrm{K}$ 大は大型の容器に麦茶, スポー
ツドリンク等を自分たちで作っていたが，作製にあた り $\mathrm{F}$ 高を除く 4 グループは容器に直接手を入れて粉 末を攪拌したり，麦茶のパックを絞っていた．

4）練習中の用便 : 各グループとも主に体育館の便 所を使用していた８月 21 日，Aスポーツの 1 名が 体育館便所前で下痢便を失禁した，清掃の際，手洗い 場の流しを使用していた。

5. クリプトスポリジウム検査

施設利用前の 8 月 18 日に発症した A スポーツの児 童 1 名を含む 4 グループにおける発症者 86 名の翼便 検査を実施した結果, 74 名 $(86.0 \%)$ の糞便からオー シストが検出された (Table 2). そのうち, A スポー ツの 18 分離株, C大の 5 分離株, D 大の 1 分離株, お よび $\mathrm{E}$ 高の 6 株はすべて Cryptosporidium hominis (C. parvumのヒト型）と同定され，遺伝子配列は全て一 致した。環境試料として採取した調理従事者の粪便, 井戸I-II 原水, 末端水 (蛇口水, 池の底泥), 水か らは，オーシストが検出されなかった。一方，プール ろ過装置内の凝集沈殿物, 粪便污染部位の床材 (毛足 の長い人工芝), 清掃に使用したタオルからはオーシ ストが検出され, 床材から分離されたクリプトスポリ ジウムの遺伝子解析の結果はC. hominisと同定され, 遺伝子配列は患者分離株と一致した（Fig. 3).

\section{考察}

クリプトスポリジウム症は人や動物等の便中に排出 されたオーシストの経口摂取により発症するが，今回 の事例では喫食との間に関係は認められなかった。 ま た，水道を介したクリプトスポリジウム集団感染は報 告されているが2) 5), 施設の水道は深井戸を使用し構 造設備に問題は認められず，水道水や水道水を用いて 作製された氷試料からクリプトスポリジウムが検出さ れなかった。

発症者は 12 グループのうち 4 グループのみに限定 され, グループ内での感染率は $45.0 \%$ から $85.1 \%$ と 
Fig. 3 Fluorescent and differential interference contrast micrographs of Cryptosporidium oocysts detected from the carpet where the fecal accident occurred.

A: Immunofluorescent micrograph using monoclonal antibody specific to Cryptosporidium oocyst demonstrated a large number of oocysts in residual fecal material on the carpet where the fecal accident occurred. B: Differential interference micrograph showing that many empty oocysts with a cleaved suture existed in the residual fecal material on the carpet. Inset shows sporozoites in an intact oocyst.
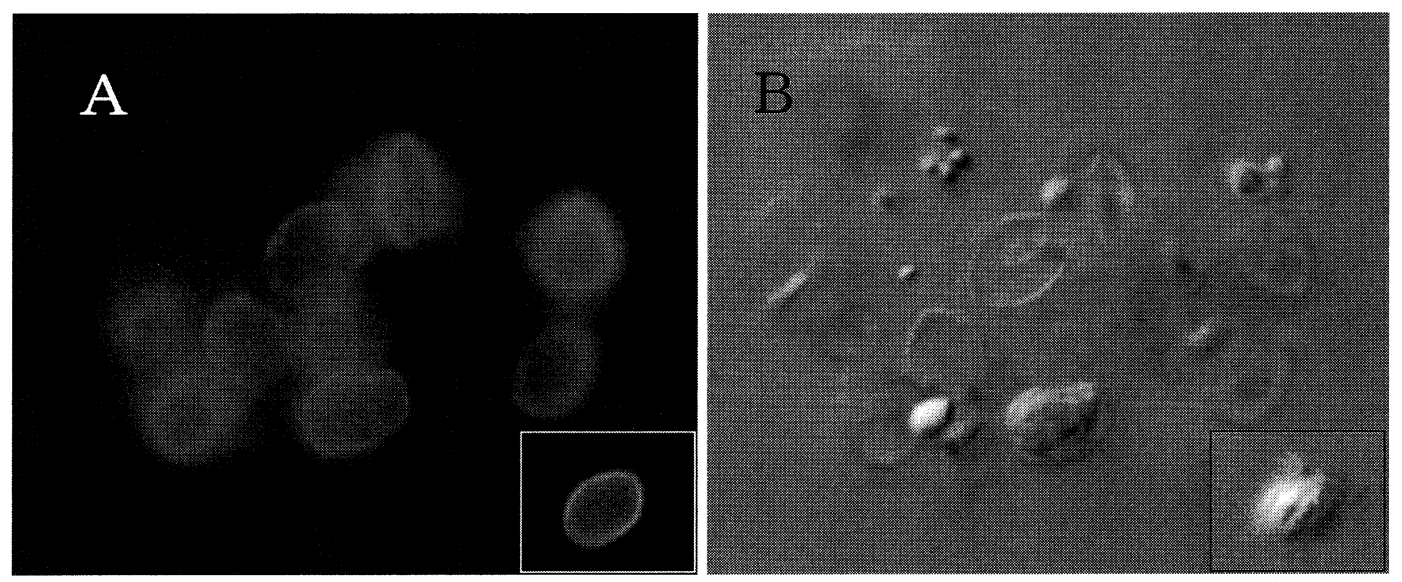

高率であった．発症グループはいずれもプール又は体 育館を利用しており，これら運動施設の利用中に暴露 された可能性が高かった.クリプトスポリジウム症の 潜伏期間は 6 日（4〜8日）と報告されていること8), ならびに患者発生曲線, グループごとの滞在期間等か ら総合的に判断すると, 8 月 21 日から 24 日までに集 中的に暴露した可能性が高かった，なお，D大の女子 では 8 月 23 日以前の発症者が複数あったが, 検査を 行った有症者 3 名からクリプトスポリジウムは検出さ れず他の原因が考えられた。

平成 16 年 9 月 7 日， 8 日には実地検分が行われた。 プールは同年 8 月 24 日に営業を終了し, 既にプール 水の排出と設備の清掃が終了していたが, 万過装置内 のろ過砂の最上部に沈積していた絮状沈殿物（凝集沈 殿物）からクリプトスポリジウムが検出され，プール 水が污染されていたことが証明された。 また, 糞便污 染部位の床材及び清掃用タオルからクリプトスポリジ ウムが検出されたことから，Aスポーツの 1 名が 8 月 21 日にはすでに発症していたこと, 潜伏期間から みて施設を訪れる前の感染であると考えられた．さら に，8月 18 日に下痢を発症したA スポーツの別の児 童からもオーシストが検出されたことから, 複数の感 染児がプールを使用していたと考えられた，感染期間 を通したオーシストの排出量は患者 1 人当たり $10^{10}$ 個 (急性期で $10^{6 \sim 7}$ 個 $/ \mathrm{g}$ ) ときわめて多量であり ${ }^{4}$, その 一方でID50 が 132 個とも 9 1,042 個とも報告され, 少量で感染が成立するといわれていること年10), 塩素 消毒に強い抵抗性を示すことから ${ }^{11)}$, 今回の事例では, 糞便によりプール水が污染され, 感染が拡大した可能 性が強く示唆された，また，感染者のいるC大，D
大，および $\mathrm{E}$ 高は，廊下の瓷便事故を清掃した際に 使用された手洗い場（流し）に扔いて, 練習中の補水 用飲料を調整する際, 直接手を入れて攪挥していた. その結果, 污染された飲料を飲み, 感染した可能性が 強く示唆された。一方， E 高と $\mathrm{F}$ 高は合同練習のた めに同施設を利用しており，滞在期間を含め同一行動 をとっていたが, 発症者の出ていない $\mathrm{F}$ 高は飲料調 整に際して直接手で攪找した行為を行っていなかっ た。

当該事例では体育館利用者から検出したクリプトス ポリジゥム，プール利用者から検出したクリプトスポ リジウムそして糞便污染場所から検出したクリプトス ポリジウムは遺伝子型が一致しており, 単一の污染源 であることが強く示唆された。

海外ではプールを介してのクリプトスポリジウム症 集団発生は多く報告されているが67)，本邦ではプール を介しての感染が示唆されたのは, 調査し得た限りで は本事例が初めてである. 本事例では, 塩素消毒等プー ルの管理は規則とおり適切になされていた。しかし， 塩素消毒に対して強い抵抗性を持つクリプトスポリジ ウムには現状の管理方法だけでは不十分であり, 新た なプール管理基準の検討が必要である，下痢のあると きはプールの使用を控えるよう利用者とプール管理者 に徹底させること，また，定期的なクリプトスポリジ ウムの水質検查を行うことが重要な対策と考えられ た。 また不適切な方法で飲料水を作成したグループに 感染者が発生したことから，改めて一般的な公衆衛生 の知識を周知することの重要性が示された.

謝辞: 今回の事例では長野県, 千葉県, 千葉市, 埼玉県, さいたま市, 厚生労働省の担当者の皆様に調查及び検查に 
おいて多大な御協力を頂いた。 また国立保健医療科学院の 国包章一先生には, 調査に際して多大な御協力を頂いた. ここに皆様に深甚なる謝意を表します。

\section{文献}

1）遠藤卓郎，八木田健司：クリプトスポリジウム. 食中毒予防必携, 日本食品衛生協会, 厚生省生 活衛生局監修, $1998 ； 287-93$.

2) 黒木俊郎, 渡辺祐子, 浅井良夫, 山井史朗, 遠 藤卓郎, 宇仁茂彦, 他 : 神奈川県内で集団発生 した水系感染 Cryptosporidium 症. 感染症誌 $1996 ; 70: 132-40$.

3) Yamamoto N, Urabe K, Takaoka M, Nakazawa K, Gotoh A, Haga M, et al. : Outbreak of cryptosporidiosis after contamination of the public water supply in Saitama Prefecture, Japan, in 1996. J J A Inf D $2000 ; 74: 518$-26.

4）遠藤卓郎, 八木田健司, 泉山信司：クリプトス ポリジゥム症 (Cryptosporidiosis). 医事新報 $2005 ; 4236: 33$-6.

5) MacKenzie WR, Hoxie NJ, Proctor ME, Gradus MS, Blair KA, Peterson DE, et al. : A massive outbreak in Milwaukee of Cryptosporidium infection transmitted through the public water supply. N Engl J Med 1994 ; 331 : 161-7.

6) Sorvillo FJ, Fujioka K, Nahlen B, Tormey MP,
Kebajian R, Mascola L : Swimming-associated cryptosporidiosis. Am J Public Health 1992 ; $82: 742-4$.

7) McAnulty JM, Fleming DW, Gonzalez AH : A community-wide outbreak of cryptosporidiosis associated with swimming at a wave pool. JAMA $1994 ; 272: 1597-600$.

8）泉山信司, 遠藤卓郎：わが国で発生したCryptosporidium 集団感染に関する考察. Clin Parasitol $2005 ; 16: 58-60$.

9) DuPont HL, Chappell CL, Sterling CR, Okhuysen PC, Rose JB, Jakubowski W: The infectivity of Cryptosporidium parvum in healthy volunteers. N Engl J Med 1995 ; 332 : 855-9.

10) Okhuysen PC, Chappell CL, Crabb JH, Sterling CR, DuPont HL : Virulence of three distinct Cryptosporidium parvum isolates for healthy adults. J Infect Dis $1999 ; 180: 1275$-81.

11) Korich DG, Mead JR, Madore MS, Sinclair NA, Sterling CR : Effects of Ozone, Chlorine Dioxide, Chlorine, and Monochloramine on Cryptosporidium parvum oocyst viability. Appl Environ Microbiol $1990 ; 56: 1423-8$.

\title{
An Outbreak of Cryptosporidiosis Associated with Swimming Pools
}

\author{
Masaaki TAKAGI'), Hiroshi TORIUMI'), Takuro ENDO ${ }^{2)}$, Norishige YAMAMOTO ${ }^{3)}$ \& Toshiro KUROKI ${ }^{4)}$ \\ ${ }^{11}$ Nagano Prefectural Hokushin Health Center, ${ }^{2}$ Department of Parasitology, National Institute of Infectious Diseases, \\ ${ }^{3}$ Department of Clinical Microbiology, Saitama Institute of Public Health, \\ ${ }^{4}$ Department of Microbiology, Kanagawa Prefectural Institute of Public Health
}

A waterborne outbreak of cryptosporidiosis occurred among visitors at a hotel with a swimming pool, gymnasium, and other sports facilities, in northern Nagano Prefecture. The outbreak began in late August, peaked on August 27 and 28, and tapered off at the beginning of September 2004. On August 30, 288 clinical cases with digestive symptoms, including watery diarrhea, vomiting, abdominal cramps and tenesmus, were reported to local authorities. Among case-patients who submitted stool samples, 74 were positive for Cryptosporidium. Descriptive epidemiology, environmental investigations, and laboratory tests suggested that a fecal accident in the swimming pool by swimmers infected before attending the summer training camp was thought to be the source of contamination, and case-patients were mostly among swimmers. Some other clinical-cases had no history of swimming in the pool during their stay and likely were infected through drinking contaminated self-made sports drinks dissolved in water from contaminated faucets and/or sinks nearby the gymnasium toilet. The sink was used to deal with the aftermath of a toilet accident at the entrance of the toilet by a swimming school attendee on August 21. This report is, to our knowledge, the first of a cryptosporidiosis outbreak associated with swimming pools in Japan. 